\title{
THE BARRIERS AND MOTIVES OF SMES INTERNATIONALIZATION: THE INSIGHTS INTO THE THEORY DEVELOPMENT
}

\author{
Renata Krikštulyte் ${ }^{1}$, Renata Korsakienè ${ }^{2}$ \\ ${ }^{1,2}$ Faculty of Business Management, Vilnius Gediminas Technical University, \\ Sauletekio al. 11, LT-10223 Vilnius, Lithuania \\ E-mails: ${ }^{1}$ r.krikstulyte@gmail.com; ${ }^{2}$ renata.korsakiene@vgtu.lt (corresponding author)
}

\begin{abstract}
SMEs are seen as the one of the main factors, impacting the growth of the national economy, contributing to the new jobs and social stability. The tendencies of political, economic and technological changes, competition in the local market, and demand of customers have encouraged the managers and entrepreneurs to be more proactive and to take greater risks in developing appropriate international strategies. The paper aims to disclose the main motives and barriers, impacting international expansion of SMEs. The research investigated the extensive number of prevailing factors and considered traditional and high-tech industries. The adopted approach let us provide the main insights into the theory development and to suggest the main propositions for the future investigations.
\end{abstract}

Keywords: barriers, motives, traditional industries, high-tech industries, internationalization, SMEs.

JEL classification: M10; M13; M16; M19.

\section{Introduction}

The fast changes of business environment have impacted the performance of business companies. The expansion of multinational companies, the growth of production and competition have encouraged the firms to seek the expansion in new markets and find the means, diminishing production and delivery costs of the products and services. Notably, international agreements of governments have influenced various changes in business environment. Therefore, the growth of international integration and globalization have diminished or eliminated the import barriers in many developed countries.

The firms' international development and the increased competition in the markets let us conclude that local markets are not protected anymore from new competitors and thus, the firms can't rely on the capacity of local market. These changes have influenced the activities of small and medium sized enterprises (SMEs) in both developed and emerging markets. SMEs are considered to be the main force, driving competitiveness of nations and regions. Hence, the tendencies of political, economic and technological changes, competition, and demand of customers have encouraged the managers and entrepreneurs to be more proactive and to take greater risks in developing appropriate business strategies. Thus, the inclination of the firms to enter international markets has been increasing.
The paper aims to disclose the main motives and barriers, impacting international expansion of SMEs. The research investigated the extensive number of prevailing factors and considered traditional and high-tech industries. The research is grounded on analysis and synthesis of prevailing scientific sources, investigating SMEs internationalization.

\section{The definition of internationalization}

SMEs are acknowledged as the main factor, impacting the growth of economy in both developed and emerging markets. The scholars conclude that SMEs predominate in private sector of majority of countries and generate more than half of work places (Hessels, Parker 2013). SMEs are vulnerable to the fierce competition and thus, aiming to expand, have to compete in international markets. Therefore, internationalization of SMEs is beneficial for the country's development, the growth and prosperity of economy and international reputation (Ruzzier et al. 2007). SMEs contribute to the increasing competitiveness at the national and regional level. Thus, various policies of the European Union and appropriate policies of the governments are focused on the promotion and development of SMEs (Korsakienè et al. 2014). The investigations of the scholars carried out over the last few decades revealed international business as the unique phenomenon. Meanwhile, the majori- 
ty of Lithuanian and foreign entrepreneurs recognized international activities as the most important in the development of the firms.

In some investigations, the concepts of international business and internationalization are interrelated together. However, these definitions should be assumed as the separate concepts. Langviniene et al. (2010) notes that, international business is seen as any activity of the firm outside the country, comprising export and import activities, production and delivery of the products and services. The definition of international business includes a number of operations: the flow of products and services, the movement of workforce and technologies, import and export, investments, tourism, banking, advertisement, construction and inter-governmental agreements. The development of these operations has been impacted by the increased pace of globalization. Globalization comprises economic integration and increased interdependence of countries (Langvinienè et al. 2010). Hence, globalization provides international opportunities and the possibilities to increase capital, production, trade and services for many firms.

Though internationalization has become a buzzword in the scientific sources, various scholars suggest different concepts. Some approaches assume that internationalization is seen as the firm's strategy, focused on the expansion of the firm's activities across national borders. The strategy provides a number of advantages: economy of scale and scope, the increased market power, lower risk, opportunities for learning and development (Lu, Beamish 2004).

Meanwhile, Albaum et al. (2005) investigated international activities of the firms and suggested much consistent definition of internationalization. The authors assume, that internationalization is seen as a long process of the firm's activities, aiming to increase performance, to gain the power in international markets and to develop closer international relationships. Agndal and Chetty (2007) defined internationalization as the process, focused on dynamic international activities of the firm and suggested the opportunities to change the strategy in different directions. Other scholars assume that internationalization is not limited by the firm's export (Singh et al. 2010). Thus, internationalization comprises trade activities, inter-governmental cooperation, establishment of alliances, joint ventures and foreign subsidiaries, which are formed taking into consideration globalization forces, social, economic and cultural circumstances. Some scholars state that internationalization is the increased process of import and export activities, impacted by the firm's international activities (Hilmersson 2014).

Internationalization of the firms has attracted the attention of Lithuanian scientists. For instance, Vaiginiene (2009) defined internationalization as the consistent process of international activities, experience and accumulation of knowledge about international markets. Prevailing conditions in the markets let the scholars to accept much broader view toward internationalization. The involvement into international trade processes, continuous development and growth of the firms as well as the development of various relationships among different institutions and industries at regional and global levels have been discussed (Jatuliavičiene 2009; Korsakienè et al. 2015). Hence, internationalization is seen as the consistent development process of international business, which contributes to the increased commitment of the firms to international markets and international operations through supply of the products and services. These activities let the firms to strengthen the involvement into international operations and thus, contribute to the increased globalization of the markets (Jatuliavičienè 2009). Some scholars suggested to consider prevailing social, economic, political and cultural context and the development of various relationships and interconnections at both regional and global levels (Urbšienè 2011). Thus, internationalization is seen as the expansion of the relationships across national borders. The opinion about internationalization as a quantitative process, related to the extensive development of relations and activities in different geographical markets, has been expressed. However, the processes of globalization and internationalization are quantitatively different. The processes of globalization comprise both the expansion of activities across national borders and the functional integration of separate activities, performed in international context.

Some scholars adopted networking approach which distinguished the role of the relationships and connections (Korsakiene 2012). Considering networking approach, the internationalization is developed:

1. Through development of relationships with partners in international markets.

2. Through strengthened trust in already established networks.

3. Through integration of the position in networks, operating in different countries.

Notably, some scholars define internationalization as global integration, contributing to the added value or a number of factors contributing to 
the export development. Meanwhile, other scholars define internationalization as the appropriate sequence of stages in international markets. The analysis let us conclude, that international business can be defined as any business transaction, performed by the firms, aiming to expand business performance and geographical markets. This definition is related to small and big firms. While SMEs aim to supply their products and services to foreign markets, big firms, relying on obtained marketing, production and financial capacity, supply products and services globally. The definition of internationalization is related to the integration processes of the firms in international market. Internationalization means the changes of current state and dynamic changes. Internationalization is carried out in the context of the firm growth. Thus, the difference between internationalization and the growth of the firm is rather conditional. Internationalization takes into consideration the aspect of time. Integration process of the firm's activities comprises consistent accumulation of knowledge and experience. Therefore, internationalization can be assumed as the process, the final outcome and the mindset of the entrepreneur.

Some scholars took the traditional approach and acknowledged the gradual involvement of the firms into international markets, which require the evaluation of opportunities and perspectives and the development of the business networks (Dunning 1994; Buckley, Casson 2002; Johanson, Mattson 1988). Traditional internationalization theories emphasize internationalization as the gradual process, taking many years of the adaptation to the context changes. Thus, only multinational firms, having strong position in the national market, many resources and experience can be involved into this process. The commitment to the international markets takes time, thus the firms slowly expand their geographical scope. This approach is relevant to many traditional exporting firms.

The researches, carried out by many scholars, let us conclude that internationalization process can be fast and overcome some traditional stages (Gabrielsson et al. 2008; Cavusgil, Knight 2015). The firms can be involved into international markets from the moment of their establishment.

The firms, planning their international activities soon after their establishment, assessing local and international markets as the one, starting international activities in the first 3 years after their establishment and generating more than $50 \%$ of sales from international markets are referred to be born global firms (Alminiene, Kuvykaite 2012). Born global firms are seen as relatively new phenomenon, attracting the focus of the researchers (Loane et al. 2014). These firms are usually SMEs, focused on high tech industries and unique niches, demonstrating entrepreneurship and orientation to innovations and accumulating unique resources. Notably, these firms have global vision, supply products or services in different markets and have competitive advantage (Lampa, Nilsson 2004). Some scholars note, that born global firms can be differentiated according to the knowledge based industries. Onkelinx et al. (2012) stated that technological competencies encourage the firms to implement international expansion earlier. On the other hand, the growth in the national markets forms preconditions to expand internationally. However, the firms which adopted different methods of internationalization demonstrate different performance (Korsakienè 2012). The capacity of the firm to enter international markets is related to the tangible and intangible resources. Notably, new and serial entrepreneurs can compensate the deficiency of capital by investing into social capital, i.e. the relationships with various stakeholders, increasing the trust in the firm, technical and financial resources (Robson et al. 2012).

\section{The motives of the firm's internationalization}

The literature provides different motives related to the firm's international expansion. While some authors distinguish only few motives, other provide more extensive list and group them according to the prevailing features. On the other hand, the groups of the motives, provided by the scholars are similar and the main difference is seen in the clasification of these groups (Žukauskas 2006). motives:

Dunning (1994) distinguished four groups of

- The motives related to the resources: lower costs of workforce, natural resources, management and technological abilities, secure supply of the resources.

- The motives related to the market: market attractiveness, the opportunity to defend current markets and exploit new markets.

- The motives related to the strategy: the aim to increase global perception of the product and to develop global network, to develop good image of the firm and increase sales.

- The motives related to the effectiveness: economy of scale and diversification of risk.

Meanwhile, other scholars provide aggressive and defensive motives, which are entitled as proac- 
tive and reactive motives of internationalization (Wattanasupachoke 2002). The proactive motives comprise the aim to increase profit/growth, the uniqueness of product/service, the opportunities in foreign markets, economy of scale, the objectives of the managers, and the exemptions from the taxes. The reactive motives comprise the competitive pressure, small national market, unutilized capacity of the firm, seasonal sales, and the contracts with international subcontractors, fluctuation of the demand, and psychic distance of international markets.

Ball et al. (2004) distinguished aggressive (the development of new markets, the increase of the profit, the development and supply of the products to the local market, the aim of the managers to expand the activities of the firm) and defensive (the protection of local market, the protection of international market, guarantees to supply necessary resources, the transfer of the technologies, geographical diversification and political stability) motives of internationalization. The scholars emphasised that aggressive motives are related to the aim to increase the profit and defensive motives to the aim to defend current position.

Notably, some authors distinguished external and internal motives (Czinkota et al. 2005). Internal motives, increasing the intentions to enter international markets, include the aim to increase profit, uniqueness of the product and available technological advantage, available information (about customers in international markets, mistakes of competitors, markets and situations in the markets), the image of the firm (the development and maintenance of good image), the means of export promotions, provided by the government, the excessive capacity of the firm in the local market. External motives include the push of competitors, overproduction, decreasing sales in national market and intense competition in national market, small distance to the clients and the harbours, the exemption from taxes in foreign markets.

Albaum et al. (2005) suggested to distinguish motives of internationalization according to the all four aspects: internal motives, related to the firm and encouraging the firm to change; external motives stemming from external environment of the firm, encouraging actively react to the external changes; aggressive motives, related to the aim to increase profit and sales; passive motives, related to the intentions maintain current profit and sales. Meanwhile, the annual report provided by OECD (Fliess, Busquets 2006) distinguished pull drivers related to the foreign country and push drivers, related to the national market.
The investigation of prevailing sources let us conclude that a number of motives encouraging expansion of the firms to foreign markets are vast. On the other hand, these motives are sensitive to the industry and the firm. We agree with the opinion of some scholars (Sekliuckiene 2009) that the decision for internationalization are determined by more than one motive.

\section{The barriers of internationalization processes}

Alongside internationalization motives, encouraging international expansion of the firm, a number of internationalization issues is distinguished. The investigation of scientific literature let us disclose, that the researchers agree upon several factors, hindering business development. The scholars suggested several approaches towards internationalization barriers.

Some scholars note that international expansion of the business is impacted by the interrelationship of internal and external factors (Wattanasupachoke 2002; Korsakiene 2014). Thus, the issues of internationalization can be distinguished into external environmental factors such as: unstable economic environment or unstable legal bases and internal environmental factors such as: business strategy, available resources and capabilities. The firms are not able to control external environment. However, external factors have to be considered if the firms aim to gain international recognition.

Business internationalization has become the main precondition for SMEs, aiming for the future growth and development. On the other hand, the firms encounter many problems in the process of internationalization. For instance, Paunović and Prebežac (2010) investigated business internationalization and emphasized that a lack of entrepreneurship, management and marketing capabilities are common barriers of SMEs internationalization (Table 1). While some barriers are relevant to all SMEs, other barriers are the consequences of the changes in business, political and economic environment.

Meanwhile Ojasalo J. and Ojasalo K. (2011) investigated business to business services and provided own classification of the barriers. The authors suggested to distinguish specific and general barriers. For instance, specific barriers are: the development of formal and informal networks; small size of the firm; the application of national standards and rules; complicated foreign legal systems; inability to operate without licence, provided by the professional organization; the need of local 
language; the difficulties to overcome psychological distance; the difficulties to provide services related to the distance; the need to be registered in the local register; very high costs of local operations; difficulties of obtaining information about competitors; very high administrative costs; the conditions of procurement; the need to provide service in foreign market; the need to develop new business model in foreign market; the reluctance of customers to pay for the services; cultural barriers; foreign language barriers.

Table 1. The barriers of internationalization (Source: Paunović, Prebežac 2010)

\begin{tabular}{|c|c|}
\hline $\begin{array}{l}\text { The lack of entrepreneurial, man- } \\
\text { agement and marketing capabili- } \\
\text { ties }\end{array}$ & IMPORTANT \\
\hline The barriers of bureaucracy & \\
\hline $\begin{array}{l}\text { Inappropriate approach towards } \\
\text { information and knowledge }\end{array}$ & \\
\hline $\begin{array}{l}\text { The difficulties to obtain financial } \\
\text { resources }\end{array}$ & \\
\hline Inaccessible investments & \\
\hline $\begin{array}{l}\text { Inadequate standards and the lack } \\
\text { of knowledge related to the quality }\end{array}$ & \\
\hline $\begin{array}{l}\text { The different application of the } \\
\text { products and services }\end{array}$ & \\
\hline $\begin{array}{l}\text { The barriers of foreign language } \\
\text { and different cultures }\end{array}$ & \\
\hline The risk related to sales & \\
\hline The competition of domestic firms & \\
\hline $\begin{array}{l}\text { Inappropriate behaviour of multi- } \\
\text { national companies regarding do- } \\
\text { mestic firms }\end{array}$ & $\begin{array}{c}\text { Less im- } \\
\text { portant }\end{array}$ \\
\hline $\begin{array}{l}\text { The difficulties related to the doc- } \\
\text { uments, including packaging and } \\
\text { labelling }\end{array}$ & \\
\hline $\begin{array}{l}\text { The lack of internationalization } \\
\text { promotion, initiated by the gov- } \\
\text { ernment }\end{array}$ & \\
\hline The lack of intellectual propriety & \\
\hline
\end{tabular}

Notably, Ojasalo J. and Ojasalo K. (2011) distinguished general barriers:

- The barriers to entry: the requirements of licences; monopolistic markets; the restrictions of services; the requirements for local ownership; very high financial requirements; the restrictions related to the workforce.

- The barriers of business operations: the discriminatory taxation; the discriminatory purchases of the government; the refusal of national associations to enter the market; the barriers to employ foreign citizens; the barriers related to the international documents or the processing of international documents; the competition of the government; the subsidies to local firms provided by the government.

Lithuanian scholars, investigating SMEs, distinguished the barriers hindering development of the business: the constant changes of legislation, the lack of initial capital, high taxes and the lack of working capital (Bartkus 2010). The investigators acknowledged that the barriers of internationalization process have influenced the decisions to enter foreign markets. Thus, internal and external barriers have been distinguished (Table 2).

Table 2. Internal and external barriers of internationalization (Source: Sekliuckienė 2013)

\begin{tabular}{lc}
\hline \multicolumn{1}{c}{ Internal barriers } & \multicolumn{1}{c}{ External barriers } \\
\hline - Organisational and & - Legal: the governmental \\
management barriers: & control and the re- \\
the lack of knowledge & strictions; the long and \\
(logistics, marketing & difficult licencing pro- \\
and management); a & cess. \\
position in the markets; & - Political: political insta- \\
inappropriate control of & bility. \\
the business opera- & - Economic: unstable eco- \\
tions; the size of the & nomic position; the con- \\
firm. & trol of foreign currency. \\
-Financial sources: a & - Market conditions: the \\
lack of financial & capacity of the market; \\
sources. & different needs of the cus- \\
- Non-financial sources: & tomers; intense competi- \\
a lack of information; a & tion. \\
lack of new services; a & - Geographical: geograph- \\
lack of human re- & ical differences. \\
sources. & - Cultural: intercultural \\
& differences; the different \\
& assessment of the prod- \\
& ucts/services; the barriers \\
& of language. \\
& Specific: the requirements \\
& of foreign country. \\
\hline
\end{tabular}

The investigation of suggested classifications let us conclude that the opinion about the importance of several impacting barriers has been prevailing. On the other hand, the approach towards the classification of internationalization barriers is rather similar. The majority of the scholars conclude that the main barriers, impacting internationalization process are: unstable legal, political and economic environment and insufficient support of the government. 


\section{Methodology}

The objective of the paper was to reveal the importance of SMEs internationalization prevailing in the scientific sources and to investigate the studies, focused on the main motives and barriers. Thus, the research was grounded on the investigation of published scientific papers. Aiming to revise prevailing sources, we selected Emerald Insight database. The database is seen as the popular scientific database, publishing scientific papers related to social sciences: marketing, management, production, economics, human resources and etc. The database includes peer reviewed scientific papers. We applied other criteria for the selection purpose: a) empirical research, b) conceptual research and c) reviews.

We took into consideration only the papers published in 2000-2015. The main keywords used for the selection were: internationalization, SMEs, barriers, motives. The citation of the papers and the title were the main criteria to select the papers for farther investigation. The sample comprised 551 scientific papers.

\section{The research results}

The selected approach let us investigate scientific studies according to the main keywords. Figure 1 provides information how the number of scientific papers has been changing considering SMEs internationalization.

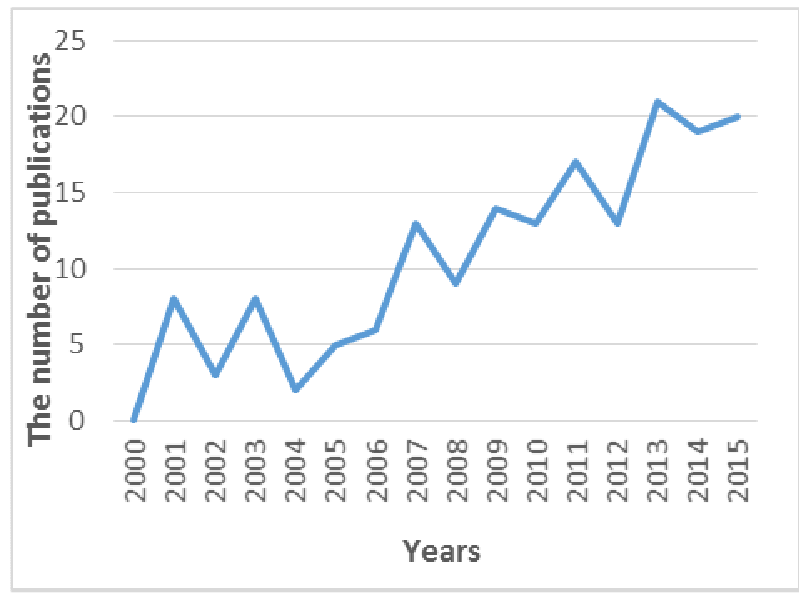

Fig. 1. The changes in the number of scientific papers, investigating SMEs internationalization in 2000-2015

(Source: Emerald Insight database)

The data let us conclude, that the topic of internationalization has become extremely popular among various scientists. On the other hand, the investigation of the publications let us reveal that the number of published papers is rather unstable the number has increased or decreased.

The number of the papers has been increasing starting from 2004. The observation let us suggest few assumptions. Firstly, globalization processes, the enlargement of the EU and the adopted policies, related to SMEs internationalization contributed to the focus of scientists and practitioners on SMEs internationalization. Secondly, global financial crisis prompted further investigations of SMEs internationalization. The scholars acknowledged the importance of SMEs in the growth of new work places and the growth of economy in general.

We also focused on the papers, investigating the main motives of SMEs internationalization. Thus, the changes in the number of published paper were considered (Fig. 2). The data let us conclude, that the number of scientific papers, investigating motives, is not stable. In some periods the number was increasing or declining.

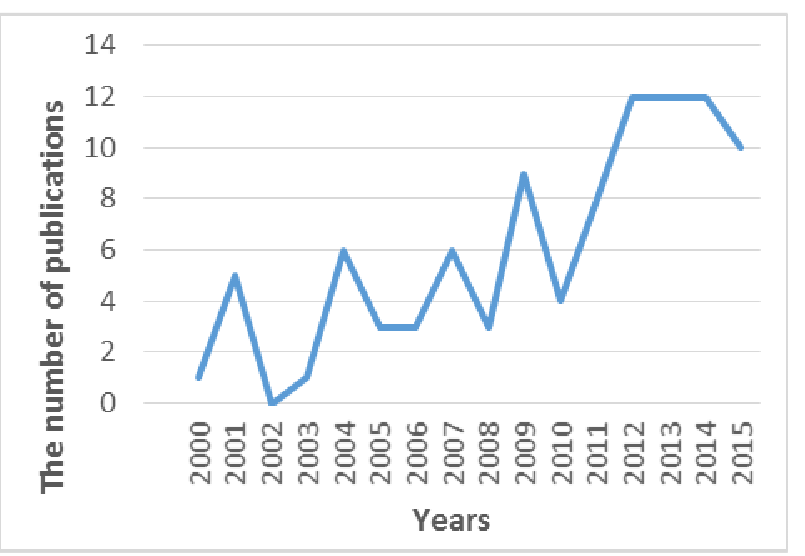

Fig. 2. The changes in the number of scientific papers, investigating motives of internationalization in 2000-2015 (Source: Emerald Insight database)

Additionally, the papers, investigating the barriers of SMEs internationalization have been taken into consideration. Figure 3 presents the changes in the number of scientific papers related to the main barriers. The data let us conclude that the interest into the barriers is unstable. Notably, the highest number of the papers was published in 2010. Thus, these data let us conclude that the focus to the barriers of internationalization was relatively higher in comparison to the motives.

We also aimed to analyse the research approaches adopted by various scholars, focused on SMEs internationalization. The analysis let us conclude that the main methods adopted by the scholars are: the survey, interview, a case study, metaanalysis and correlation-regression analysis. Notably, the survey is seen as the most popular method 


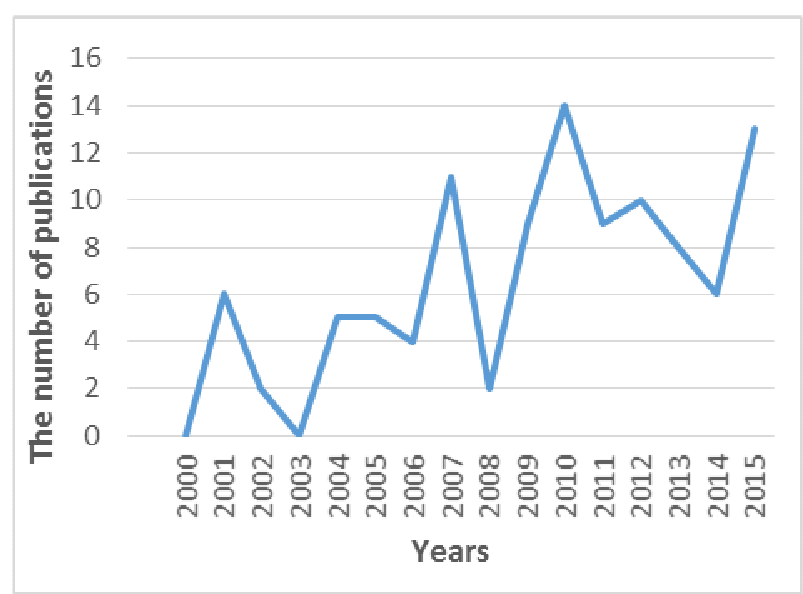

Fig. 3. The changes in the number of scientific papers, investigating barriers of internationalization in 20002015 (Source: Emerald Insight database)

of data collection. Meanwhile, some scholars relied on secondary source of information collection and focused on professional business journals and etc.

The selection of the respondents is rather different. While some scholars focused on SMEs, operating in particular industries, other scholars selected the firms randomly and rely on various industries. We focused on the sources, investigating the barriers and motives and considered traditional and high-tech industries. Notably, the investigations relied on rather small sample of SMEs. For instance, some studies included only few respondents (Gardo et al. 2015). The scholars aimed to target managers or owners of SMEs as the main source of information. Meanwhile, some studies included experts (Gardo et al. 2015). The analysis of traditional and high-tech industries let us gain insights into the different barriers. For instance, the lack of specific knowledge and information are seen as the most common barriers for high-tech industry firms (Todd, Javalgi 2007; Sedoglavich 2012). Meanwhile, SMEs operating in traditional industries are exposed by many prevailing barriers. The analysis of the main motives let us conclude that prevailing technologies and obtained resources are the main motives of high-tech SMEs (Todd, Javalgi 2007; Kenny, Fahy 2011). Meanwhile, traditional SMEs indicate various prevailing motives.

\section{Conclusions}

SMEs are the main factor, increasing competitiveness at the national and regional level. Thus, SMEs influence the growth of economy in both developed and emerging markets. The scholars conclude that SMEs predominate in private sector of majority of countries and generate more than half of work places. Internationalization of SMEs is beneficial for the country's development, the growth and prosperity of economy and international reputation. Thus, various policies of the European Union and appropriate policies of the governments are focused on the development and promotion of SMEs.

The investigation of scientific sources let us conclude, that internationalization of SMEs can be fast and the firms can be involved in international markets soon after their establishment. The available resources are the main precondition to start the business abroad. On the other hand, some SMEs take traditional approach and internationalize their activities after the establishment in the national market. The literature provides different motives related to the firm's international expansion. However, various classifications of motives provided by the scholars are rather similar. The most common motives indicated by different scholars are: the objectives to gain higher profit and growth, less expensive resources, the attractiveness of new markets, economy of scale and diversification of the risk. In addition to business internationalization motives, encouraging the firm's international expansion, a number of issues related to the internationalization process are distinguished.

Majority of scholars suggested the main barriers of SMEs internationalization such as: unstable legal, political and economic environment, the lack of knowledge and inappropriate support of the government. Notably, an extensive number of internationalization motives and barriers let us state that these factors have to be investigated considering the context of SMEs.

The observation of scientific papers included into Emerald Insight database let us suggest few assumptions. Firstly, globalization processes, the enlargement of the EU and the adopted policies, related to SMEs internationalization contributed to the focus of scientists and practitioners on SMEs internationalization. Secondly, global financial crisis prompted further investigations of SMEs internationalization. Thus, the number of publications related to SMEs internationalization has been increasing. On the other hand, the focus of the scholars to the barriers of internationalization was relatively higher than the motives. The analysis of traditional and high-tech industries let us gain insights into the different barriers. The lack of specific knowledge and information are seen as the most common barriers for high-tech industry firms. Meanwhile, SMEs operating in traditional industries are exposed by many prevailing barriers. Considering motives, the prevailing technologies and obtained resources are the main motives of high- 
tech SMEs. Meanwhile, traditional SMEs indicate various prevailing motives.

Further researches have to be related to the application of scientific methods enabling to assess the motives and barriers of SMEs. For instance, multiple-criteria decision analysis (MCDA) is seen as the method enabling to get new insights into SMEs internationalization processes and internationalization scope. We believe that our research is beneficial for the managers and policy makers, related to the SMEs activities.

The recommendations for policy makers are: to encourage active internationalization of SMEs, to help in developing networks and appropriate knowledge. The managers of SMEs have to be encouraged to take benefits provided by the EU support.

The recommendations for the managers are: to encourage constant development of employees, participation in various training programmes and to establish close cooperation with science and education institutions.

\section{References}

Agndal, H.; Chetty, S. 2007. The impact of relationships on changes in internationalisation strategies of SMEs, European Journal of Marketing 41(11/12): 1449-1474. http://dx.doi.org/10.1108/03090560710821251

Albaum, G.; Duerr, E.; Strandskov, J. 2005. International marketing and export management. $5^{\text {th }}$ ed. Pearson Education.

Alminienè, M.; Kuvykaite, R. 2012. Lyginamoji Lietuvos gimusiu globaliomis imoniu ir tradiciniu eksportuotojų marketingo sprendimų analizè, Economics and Management 17(3): 1084-1097.

Ball, D. A.; McCulloch, W. H.; Frantz, P. L.; Geringer, J. M.; Minor, M. S. 2004. International business: the challenge of global competition. $9^{\text {th }}$ ed. New York: McGraw Hill.

Bartkus, E. V. 2010. Smulkaus ir vidutinio verslo plètros prognozès Lietuvoje ekonominès krizès pradžioje, Ekonomika ir vadyba 15: 390-396.

Buckley, P. J.; Casson, M. 2002. The future of the multinational enterprise. Palgrave Macmillan.

Cavusgil, S. T.; Knight, G. 2015. The born global firm: an entrepreneurial and capabilities perspective on early and rapid internationalization, Journal of International Business Studies 46: 3-16. http://dx.doi.org/10.1057/jibs.2014.62

Czinkota, M. R.; Ronkainen, I. A.; Moffett, M. H. 2005. International business. $7^{\text {th }} \mathrm{ed}$. USA: Thomson.

Dunning, J. H. 1994. Multinational enterprises and the global economy. Workingham: Addison - Weslay.
Emerald Insight database [online]. 2016 [cited 29 January 2016]. Available from Internet: http://www.emeraldinsight.com

Fliess, B.; Busquets, C. 2006. The role of trade barriers in SME internationalisation. OECD Trade Policy, No. 45, OECD Publishing. http://dx.doi.org/10.1787/246707602042

Gabrielsson, M.; Kirpalani, V. H. M.; Dimitratos, P.; Solberg, C. A.; Zucchella, A. 2008. Born globals: propositions to help advance the theory, International Business Review 17(4): 385-401. http://dx.doi.org/10.1016/j.ibusrev.2008.02.015

Gardo, F. T.; Garcia, H. C.; Descals, A. M. 2015. Internationalization of SME retailer: barriers and the role of public support organizations, International Journal of Retail \& Distribution Management 43(2): 183-200.

http://dx.doi.org/10.1108/IJRDM-07-2013-0146

Hilmersson, M. 2014. Small and medium-sized enterprise internationalisation strategy and performance in times of market turbulence, International Small Business Journal 32(4): 386-400. http://dx.doi.org/10.1177/0266242613497744

Hessels, J.; Parker, S. C. 2013. Constraints, internationalization and growth: a cross - country analysis of European SMEs, Journal of World Business 48: 137-148. http://dx.doi.org/10.1016/j.jwb.2012.06.014

Jatuliavičienè, G. 2009. Integruota eksporto plètra globalizacijos salygomis: daktaro disertacija. Vilniaus universitetas, Vilnius, Lietuva (in Lithuanian).

Johanson, J.; Mattson, L. G. 1988. Internationalization in industrial systems - a network approach, in N. Hood, J.-E. Vahlne (Eds.). Strategies in global competition. London: Croom Helm.

Kenny, B.; Fahy, J. 2011. Network resources and international performance of high tech SMEs, Journal of Small Business and Enterprise Development 18(3): 529-555.

http://dx.doi.org/10.1108/14626001111155691

Korsakienè, R. 2012. Konkurencini pranašumą lemiantys veiksniai ir internacionalizacija: sasajų tyrimas, Verslas: teorija ir praktika 13(4): 283-291. http://dx.doi.org/10.3846/btp.2012.30

Korsakienė, R.; Diskiené, D.; Smaliukienė, R. 2015. Institutional theory perspective and internationalization of firms. How institutional context influences internationalization of SMEs?, Entrepreneurship and Sustainability Issues 2(3): 142-153. http://dx.doi.org/10.9770/jesi.2014.2.3(3)

Korsakienè, R.; Diskienè, D.; Drūteikienè, G. 2014. The role of human capital and organizational learning in internationalization of SMEs, in $8^{\text {th }}$ International Scientific Conference "Business and Management 2014", 15-16 May 2014, Vilnius, Lithuania.

Langvinienè, N.; Sekliuckienè, J.; Vengrauskas, P. V. 2010. Tarptautinis verslas. Kaunas: Technologija. 
Lampa, P.; Nilsson, L. 2004. Born globals - a new phenomenon in the field of internationalisation: Bachelor dissertation. Kristianstad University College, Sweden.

Loane, Sh.; Bell, J.; Cunningham, I. 2014. Entrepreneurial founding team exits in rapidly internationalizing SMEs: a double edged sword, International Business Review 23: 468-477. http://dx.doi.org/10.1016/j.ibusrev.2013.11.006

Lu, J.; Beamish, P.W. 2004. International diversification and firm performance: the S-curve hypothesis, Academy of Management Journal 47(4): 598-609. http://dx.doi.org/10.2307/20159604

Ojasalo, J.; Ojasalo, K. 2011. Barriers to internationalization of b-to-b services: theoretical analysis and empirical findings, International Journal of Systems Applications, Engineering \& Development 1(5): 109-116.

Onkelinx, J.; Manolova, T. S.; Edelman, L. F. 2012. The role of employee human capital in the accelerated internationalization of SMEs: empirical evidence from Belgium, Frontiers of Entrepreneurship Research 32(16): 1-15.

Paunović, Z.; Prebežac, D. 2010. Internationalization of small and medium-sized enterprises, Market 22(1): 57-76.

Robson, P. J. A.; Akuetteh, Ch. K.; Westhead, P.; Wright, M. 2012. Exporting intensity, human capital and business ownership experience, International Small Business Journal 30(4): 367-387. http://dx.doi.org/10.1177/0266242610364426

Ruzzier, M.; Antoncic, R.; Hisrich, D.; Konecnik, M. 2007. Human capital and SME internationalization: a structural equation modeling study, Canadian Journal of Administrative Sciences 24(1): 1529. http://dx.doi.org/10.1002/cjas.3
Sedoglavich, V. 2012. Technological imperatives in the internationalization process: results from a qualitative investigation of high-tech SMEs, Management Research Review 35(5): 441-459. http://dx.doi.org/10.1108/01409171211222386

Sekliuckienè, J. 2009. Tarptautinio verslo organizavimas. Kaunas: Technologija.

Sekliuckienè, J. 2013. Lithuanian companies in emerging markets: internationalization motives and barriers, Economics and Management 18(1): 124 133. http://dx.doi.org/10.5755/j01.em.18.1.3782

Singh, G.; Pathak, R. D.; Naz, R. 2010. Issues faced by SMEs in the internationalization process: results from Fiji and Samoa, International Journal of Emerging Markets 5(2): 153-182. http://dx.doi.org/10.1108/17468801011031801

Todd, P. R.; Javalgi, R. G. 2007. Internationalization of SMEs in India: fostering entrepreneurship by leveraging information technology, International $\mathrm{J}_{O}$ urnal of Emerging Markets 2(2): 166-180. http://dx.doi.org/10.1108/17468800710739234

Urbšienè, L. 2011. Globalizacijos samprata: šiuolaikiniai požiūriai, Verslas: teorija ir praktika 12(3): 203-214.

Vaiginienè, E. 2009. Imonès veiklos internacionalizacija kintančioje verslo aplinkoje: daktaro disertacija. Vilniaus universitetas, Vilnius, Lietuva (in Lithuanian).

Žukauskas, P. 2006. Kompaniju veiklos internacionalizacija: teorija ir praktika. Kaunas: VDU.

Wattanasupachoke, T. 2002. Internationalisation: motives and consequences, ABAC Journal 22(30): 16-30. 